\title{
Erosion-deposition and land use/land cover of the Brahmaputra river in Assam, India
}

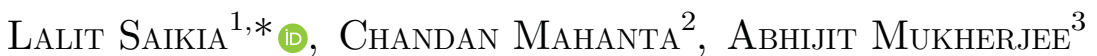 \\ and Suranjana Bhaswati Borah ${ }^{4}$ \\ ${ }^{1}$ Department of Earth Science, University of Science and Technology Meghalaya, 9th Mile, Meghalaya, India. \\ ${ }^{2}$ Department of Civil Engineering, Indian Institute of Technology Guwahati, Guwahati, India. \\ ${ }^{3}$ Department of Geology and Geophysics, Indian Institute of Technology Kharagpur, Kharagpur, India. \\ ${ }^{4}$ Department of Environmental Science, Tezpur University, Tezpur, India. \\ *Corresponding author.e-mail: lalitsaikia@yahoo.com lalit.s@alumni.iitg.ac.in
}

MS received 16 August 2018; revised 17 May 2019; accepted 24 May 2019

The Brahmaputra is a unique dynamic river in the world with intense braiding and critical bank erosion. Both erosion and deposition are continuous processes in the river in an attempt to reach a new equilibrium in channel geometry and morphology by the ever dynamic nature of flow. Erosion and deposition of the river have link to land use and land cover (LULC) as the land cover is under constant change in a dynamic landscape constantly shaped by continuous erosion and deposition. The objective of the present work is to evaluate the extent of erosion and deposition along the Brahmaputra river and change in the LULC of the Brahmaputra river in Assam, India. Remote sensing and geographic information system (GIS) techniques were utilised to extract information from Landsat images. Total area of erosion and deposition during 1973-2014 was 1557 and $204 \mathrm{~km}^{2}$, respectively. Increase in area (28\%) of the Brahmaputra during 1973-2014 is not solely due to bank erosion, but also for the bifurcation of streams without the loss of land. LULC study has revealed that $29 \%$ area was occupied by active channels and $71 \%$ was occupied by bars in 2014. Maximum reaches experienced reduction of the submerged part in 2014 compared to 1994 in the post-monsoon months with an overall decrease from $37 \%$ to $29 \%$. A reduction in natural grassland and forest has been observed with a corresponding increase in agricultural practices in different bars and islands of the Brahmaputra in Assam during 1994-2014.

Keywords. Alluvial river; erosion-deposition; LULC; Brahmaputra; Assam.

\section{Introduction}

Erosion, transportation and deposition are the three major processes in a fluvial system (Schumm 1977) that are influenced by the supply of the sediment at the upstream end and sediment that is locally eroded from the bed and banks (Charlton 2008). Thus, the morphological changes of an alluvial river channel are the consequence of sediment erosion, sediment transport and sedimentation in the river Published online: 27 July 2019
(Church 2006). Different categories of alluvial river patterns, i.e., straight, meandering and braided rivers (Leopold and Wolman 1957) are due to the sediment supply along with the flow regime. Braided rivers are those that flow in two or more channels around alluvial bars or islands. The primary causes of braided channels are the overloading of sediments and steep slopes (Lane 1957). Highly variable discharge, erodible banks and a high width/ depth ratio are the other factors responsible for 
braiding (Schumm and Kahn 1972; Knighton 1998). They have a braided look at the low flow stages with exposed bars, but all or some of the bars are submerged during the high flow stages.

The Brahmaputra is an extremely dynamic and predominantly braided river (Coleman 1969) in the world. The Brahmaputra originates as the Yarlung Tsangpo from the Angsi glacier near the Manasarovar lake in the Kailash range in southern Tibet, and it is a trans-boundary river flowing from the Himalayas to the Bay of Bengal through China (Tibet), India and Bangladesh. The river is unique due to its peculiar drainage pattern, diverse geological setting, high sediment load and critical bank erosion problem (Mahanta and Saikia 2015). The Brahmaputra supplies an estimated 1000 million ton of suspended material to the Bay of Bengal (Milliman and Meade 1983; Milliman and Syvitski 1992; Hay 1998). There is an additional strong indication that erosion is a major factor of river instability in the Brahmaputra due to the very large amount of sediment intrusion from bank erosion itself. This sediment causes further instability downstream, triggers more bank erosion, and apart from the loss of land and flood protection, hampers navigation (ADB 2007). The valley of the Brahmaputra river has been facing a heavy instability of landmass due to river bank erosion, believed to be accelerated after the 1950 earthquake. The stretch falling within Assam, India, has already lost about $7.4 \%$ of its total land due to bank erosion and channel migration (Kakati and Changkakati 2013). Erosion during 1990-2008 in the north bank and south bank of the Brahmaputra (within Assam) were 544 and $920 \mathrm{~km}^{2}$, respectively, whereas the corresponding amount of deposition were 145 and $68 \mathrm{~km}^{2}$ (Sarkar et al. 2012). The recurrent erosion has caused irreparable damage to many important places along the river bank in addition to the permanent loss of cultivable and homestead lands.

Both erosion and deposition are continuous processes in the river in an attempt to reach a new equilibrium in channel geometry and morphology by ever dynamic nature of flow. Erosion and deposition of the river has link to land use and land cover (LULC) since the land cover is under constant change in a dynamic landscape constantly shaped by continuous erosion and deposition. The objective of the present work is to evaluate the extent of erosion and deposition along the Brahmaputra river and change in the LULC of the river. In the postmonsoon season, the most important use of the LULC study is to evaluate the newly emerged morphology after the flood and erosion events. This will help in planning mitigation measures for both flood and erosion in a correct perspective, instead of drawing from the morphology of the previous year which undergoes much change during the monsoon flood. In this paper, the erosion and deposition behaviour of the Brahmaputra river was directly studied for 1973 and 2014. LULC due to erosion and deposition was studied for a later period covering 20 yrs, i.e., 1994-2014. Time periods of 1973-2014 for the erosion-deposition study and 1994-2014 for the LULC study were chosen as per the availability of satellite data and to study the change during the 20 -yr period.

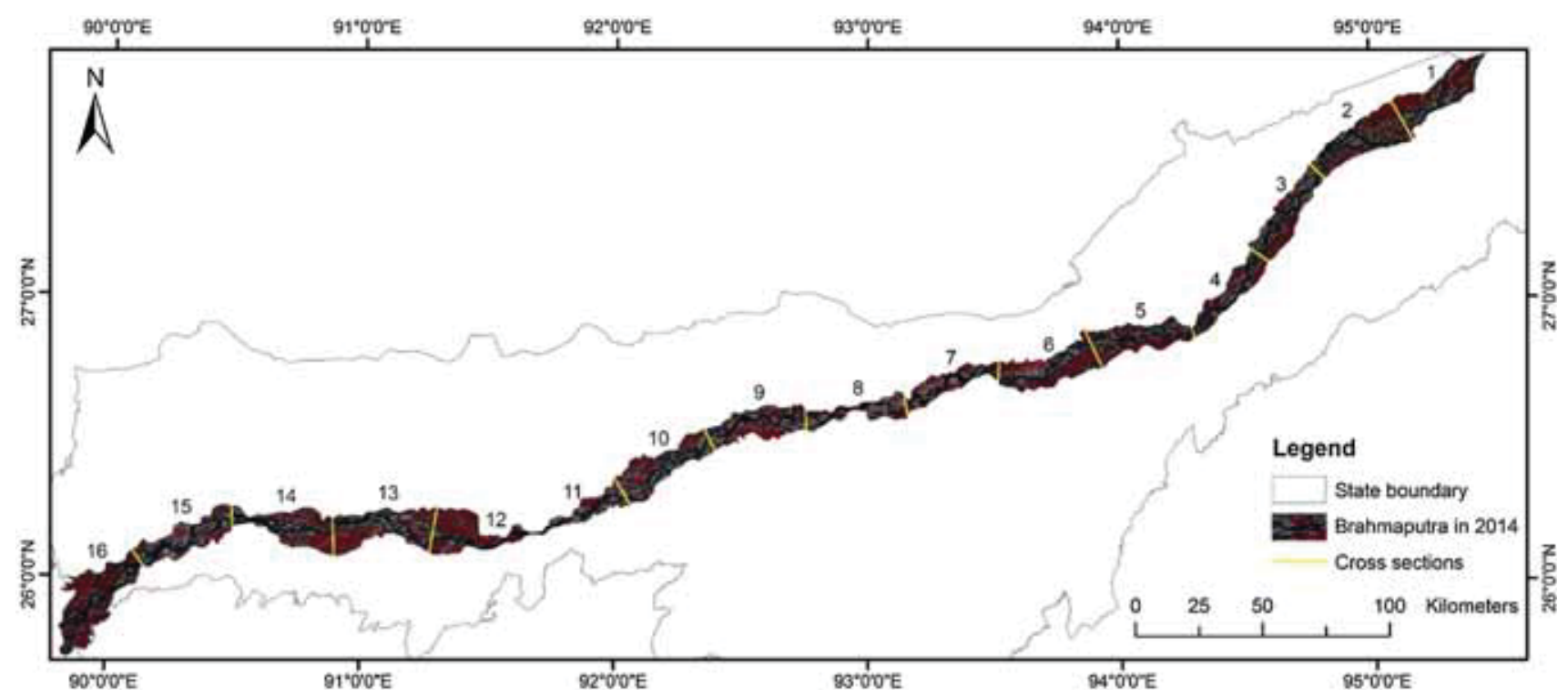

Figure 1. Map showing different reaches of the Brahmaputra river in Assam. 


\section{Materials and methods}

The erosion-deposition of the Brahmaputra river for the period 1973-2014 was studied from Landsat images using remote sensing (ERDAS Imagine) and GIS techniques (ArcGIS 10.1).

Images were procured for the same season of the year to minimise the inconsistencies in the data. Post-monsoon data were used due to low cloud cover and proper channel and sandbar definition available during this season. Raw data consisting of individual bands of each satellite image were combined in ERDAS Imagine image processing software to create a composite image. The images were then

Table 1. Satellite dataset used.

\begin{tabular}{|c|c|c|c|c|}
\hline $\begin{array}{l}\text { Sl. } \\
\text { no. }\end{array}$ & Sensor & $\begin{array}{c}\text { Path/ } \\
\text { row }\end{array}$ & $\begin{array}{c}\text { Date of } \\
\text { acquisition }\end{array}$ & $\begin{array}{c}\text { Spatial } \\
\text { resolution } \\
(\mathrm{m})\end{array}$ \\
\hline 1 & MSS & $145 / 41$ & 15-11-1973 & 60 \\
\hline 2 & MSS & $146 / 41$ & 16-11-1973 & \\
\hline 3 & MSS & $147 / 41$ & 05-12-1973 & \\
\hline 4 & MSS & $147 / 42$ & 22-11-1973 & \\
\hline 5 & MSS & $148 / 42$ & 21-02-1973 & \\
\hline 6 & TM & $135 / 41$ & 20-11-1994 & 30 \\
\hline 7 & TM & $136 / 41$ & 26-10-1994 & \\
\hline 8 & $\mathrm{TM}$ & $136 / 42$ & 26-10-1994 & \\
\hline 9 & TM & $137 / 42$ & 01-10-1994 & \\
\hline 10 & TM & $138 / 42$ & 11-12-1994 & \\
\hline 11 & OLI & $135 / 41$ & 27-11-2014 & \\
\hline 12 & OLI & $136 / 41$ & 18-11-2014 & \\
\hline 13 & OLI & $136 / 42$ & 18-11-2014 & \\
\hline 14 & OLI & $137 / 42$ & 09-11-2014 & \\
\hline 15 & OLI & $138 / 42$ & 02-12-2014 & \\
\hline
\end{tabular}

pre-processed for image enhancement techniques like haze reduction, brightness and contrast to make the process of information extraction easier. Images were then stitched to create a single seamless mosaic image for the entire stretch of the river which was utilised to visually interpret and extract the bank line. The Brahmaputra river in Assam in three different years, i.e., 1973, 1994 and 2014 was divided into 16 reaches at a length of $40 \mathrm{~km}$ and the reaches were numbered from 1 upstream to 16 downstream as shown in figure 1. Erosion-deposition and LULC were studied for different reaches to know the longitudinal variation.

LULC analysis for 1994-2014 was carried out by categorising the Landsat images (table 1) into different classes, i.e., river/water, sandbar, vegetation (including natural grass land) and agriculture (including human settlement), using unsupervised classification in image processing software, i.e., ERDAS Imagine. Error in the unsupervised classification of the LULC maps of 1994 and 2014 were $15 \%$ and $12.5 \%$, respectively. The overall classification accuracy was $85 \%$ and $87.5 \%$ in 1994 and 2014, respectively (table 2 ).

\section{Results and discussions}

\subsection{Erosion and deposition in the Brahmaputra in Assam}

Both erosion and deposition of the channel materials continue to be happening constantly. Erosion and deposition in both the banks of the Brahmaputra river in Assam during 1973-2014 are shown

Table 2.. Error matrices.

\begin{tabular}{|c|c|c|c|c|c|c|c|}
\hline \multirow[b]{2}{*}{ Classified data } & \multicolumn{4}{|c|}{ Reference data } & \multirow{2}{*}{$\begin{array}{c}\text { Producer } \\
\text { accuracy }(\%)\end{array}$} & \multirow{2}{*}{$\begin{array}{c}\text { User accuracy } \\
(\%)\end{array}$} & \multirow[b]{2}{*}{ Kappa } \\
\hline & River & Sandbar & Agriculture & Vegetation & & & \\
\hline \multicolumn{8}{|c|}{ Error matrix for 2014 classification } \\
\hline River & 10 & 0 & 0 & 0 & 90.91 & 100 & 1 \\
\hline Sandbar & 0 & 10 & 0 & 0 & 71.43 & 100 & 1 \\
\hline Agriculture & 1 & 2 & 7 & 0 & 100.00 & 70 & 0.6364 \\
\hline Vegetation & 0 & 2 & 0 & 8 & 100.00 & 80 & 0.75 \\
\hline Overall classification accuracy & & & $87.50 \%$ & & & & \\
\hline Overall kappa statistics & & & 0.83 & & & & \\
\hline \multicolumn{8}{|c|}{ Error matrix for 1994 classification } \\
\hline Water & 8 & 2 & 0 & 0 & 80.00 & 80 & 0.7333 \\
\hline Sand & 0 & 9 & 0 & 1 & 81.82 & 90 & 0.8621 \\
\hline Agriculture & 1 & 0 & 8 & 1 & 100.00 & 80 & 0.75 \\
\hline Vegetation & 1 & 0 & 0 & 9 & 81.82 & 90 & 0.8621 \\
\hline Overall classification accuracy & & & $85.00 \%$ & & & & \\
\hline Overall kappa statistics & & & 0.8 & & & & \\
\hline
\end{tabular}


in figure 2 with course of the main channel in different reaches. The reasons for the spatio-temporal variability in the erosion processes are dynamically linked to hydrological (high water discharge, high sediment load), hydraulic (intense and erratic braiding, unequal discharge and intensity of channels, angle at which the channel approaches the bank line, poor drainage and interspersed layers of sand), geochemical (organic content, particle size distribution) and geotechnical factors (low cohesion and low internal friction of bank materials).

The migration of the main channel and erosion-deposition in the Brahmaputra during 1973-2014 are shown in figure 3. There was severe erosion in the south (left) bank of the river during 1973-2014 with the downward shifting of the main channel in the first two reaches. The area under erosion in the first two reaches (reach no. 1 and 2) was $128 \mathrm{~km}^{2}$ of which $101 \mathrm{~km}^{2}$ was in the south bank. Places like Rohmoria were highly affected from the erosion problem. Compared to erosion $\left(128 \mathrm{~km}^{2}\right)$, there was low deposition $\left(6 \mathrm{~km}^{2}\right)$ in the first two reaches during 1973-2014.

Reach no. 3 experienced the least erosion (35 $\mathrm{km}^{2}$ ) among all the reaches. Higher erosion was observed in the north bank than the south bank at reach no. $3,4,5,6,8,9,11,13,14,15$ and 16. However, the extent of erosion was more in the south bank at reach no. 1, 2, 7, 10 and 12 . More than $100 \mathrm{~km}^{2}$ area was affected by erosion in the reach no. 5, 6, 10, 13 and 16. High erosion area in these reaches was mainly due to two factors:

(i) Migration of the main channel with the loss of land in reach no. $1,2,5,6,7,8,10,12,13,14$, 15 and 16.

(ii) Bifurcation of distributaries or migration of mid-channels with the development of sandbars or islands in reach no. 3, 4, 9, 11 and 16 .

Deposition was comparatively lesser in all the reaches. No deposition was observed in reach no. 12 and 16. Total area of erosion during 1973-2014 was $1557 \mathrm{~km}^{2}$ out of which $728 \mathrm{~km}^{2}$ was in the north bank and $829 \mathrm{~km}^{2}$ in the south bank of the river. The area of deposition during the period was 204 $\mathrm{km}^{2}$ with $122 \mathrm{~km}^{2}$ in the north bank and $82 \mathrm{~km}^{2}$ in the south bank. Thus, the south bank experienced higher erosion whereas deposition was prominent in the north bank of the river.

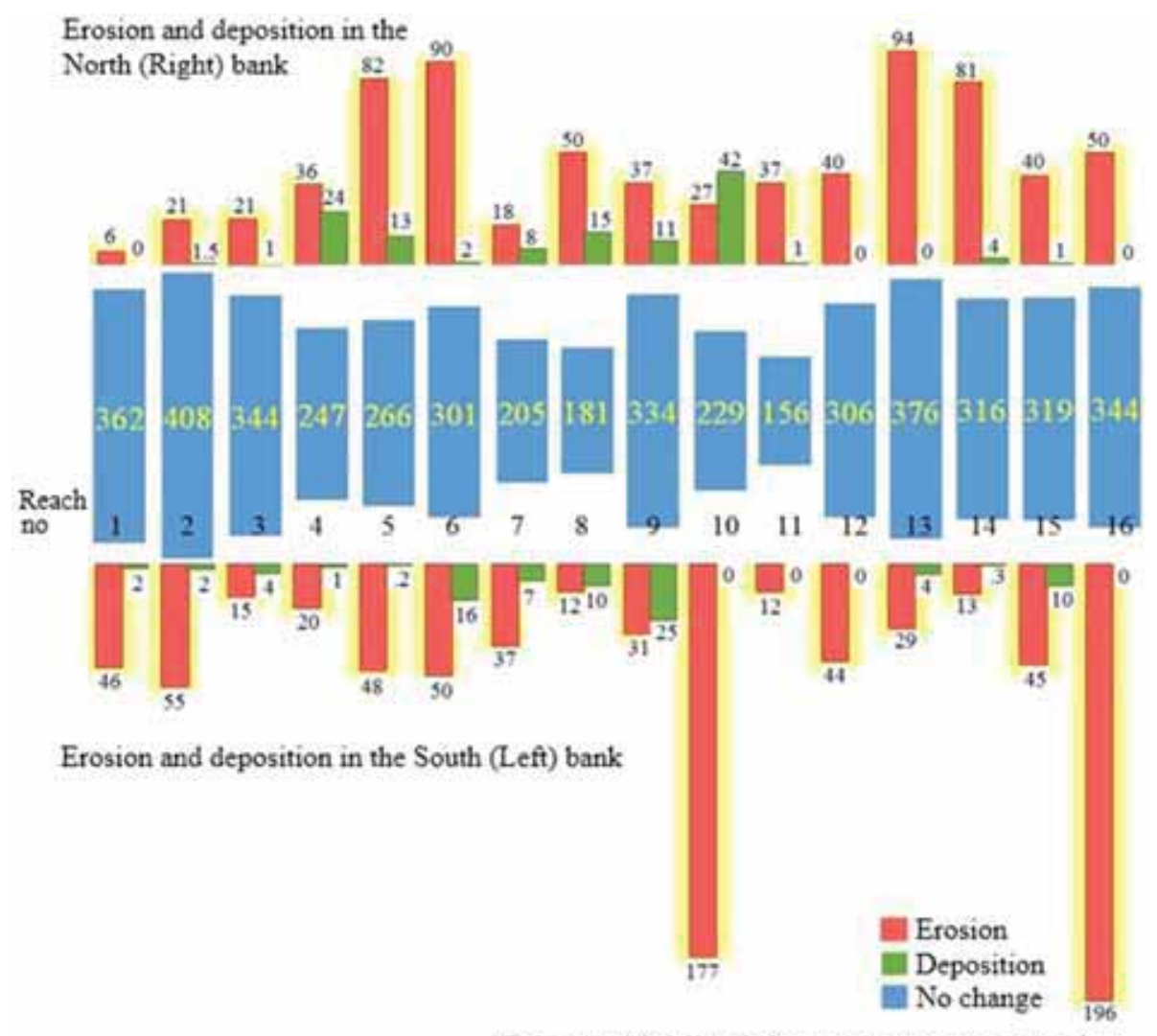

(Figure insidel outside bar represents area in sq. km)

Figure 2. Bank erosion and deposition in different reaches of the Brahmaputra in Assam, India during 1973-2014. 


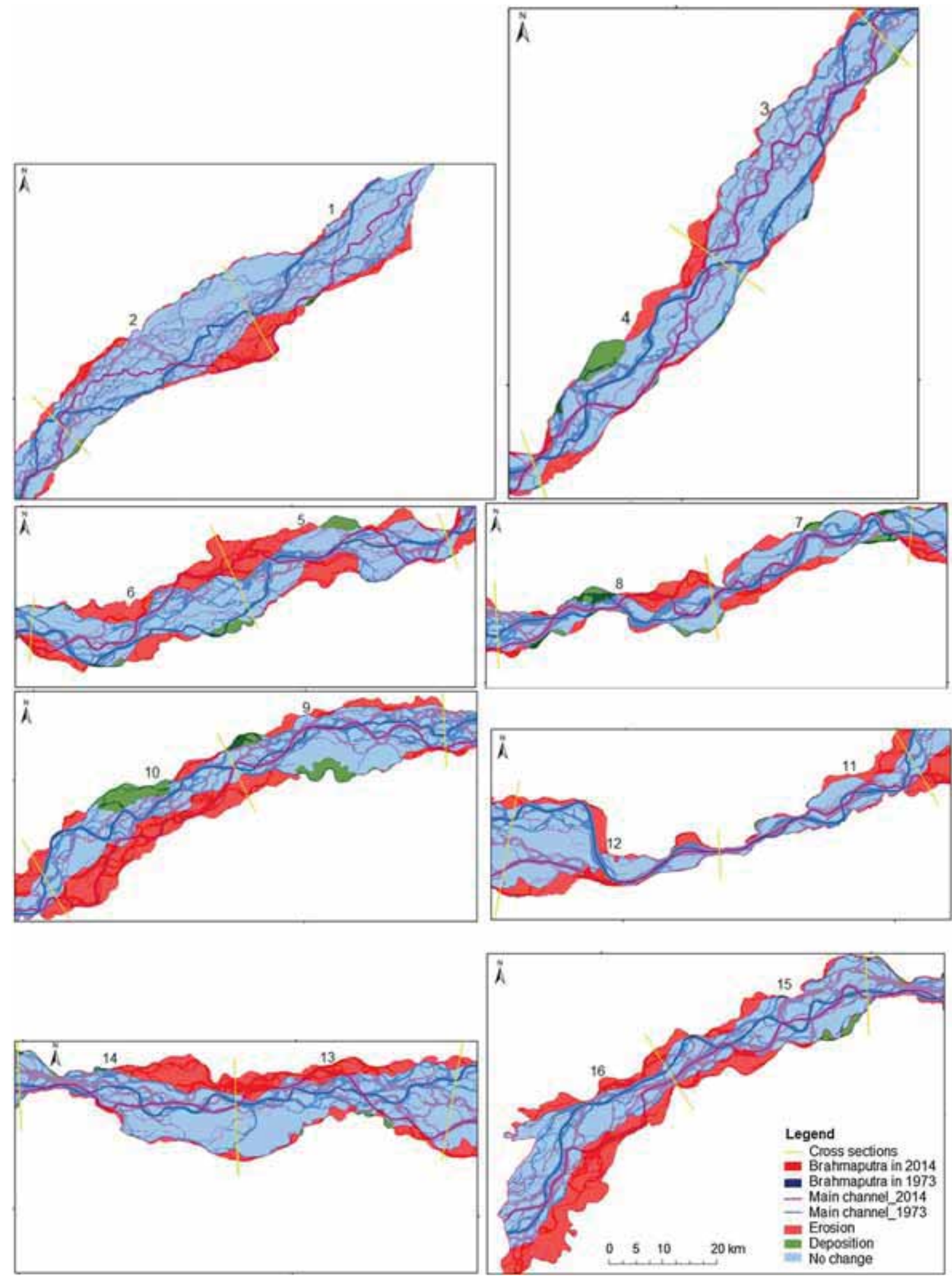

Figure 3. Migration of the main channel and erosion-deposition in the Brahmaputra during 1973-2014.

Unequal erosion in both banks of the Brahmaputra is unique compared to other Tibetan rivers like the Yellow. Bank retreat on both sides of the Yellow River from 1958 to 2008 was almost equal as the erosional area on the left bank and the right bank was 257.3 and $261.09 \mathrm{~km}^{2}$, respectively (Yao et al. 2011). But in the Brahmaputra, higher erosion in the south bank is mainly due to the downward shifting of the main channel in most of the reaches. Maximum shifting of the main channel 
Table 3. LULC of the Brahmaputra river in 1994.

\begin{tabular}{|c|c|c|c|c|c|c|c|c|c|}
\hline \multirow[b]{3}{*}{ Reach no. } & \multicolumn{5}{|c|}{ Area $\left(\mathrm{km}^{2}\right)$} & & & & \\
\hline & \multirow[b]{2}{*}{ Water } & \multicolumn{3}{|c|}{ Sandbar/Island } & \multirow[b]{2}{*}{ Total } & \multicolumn{4}{|c|}{ Area covered (\%) } \\
\hline & & Sand & Agriculture & Vegetation & & Water & Sand & Agriculture & Vegetation \\
\hline 1 & 84 & 149 & 63 & 103 & 398 & 21 & 37 & 16 & 26 \\
\hline 2 & 112 & 184 & 94 & 65 & 455 & 25 & 40 & 21 & 14 \\
\hline 3 & 115 & 151 & 0 & 104 & 371 & 31 & 41 & 0 & 28 \\
\hline 4 & 88 & 126 & 14 & 86 & 313 & 28 & 40 & 4 & 27 \\
\hline 5 & 93 & 140 & 57 & 95 & 385 & 24 & 36 & 15 & 25 \\
\hline 6 & 106 & 122 & 100 & 74 & 401 & 26 & 30 & 25 & 18 \\
\hline 7 & 110 & 72 & 8 & 60 & 250 & 44 & 29 & 3 & 24 \\
\hline 8 & 100 & 54 & 20 & 45 & 218 & 46 & 25 & 9 & 20 \\
\hline 9 & 144 & 93 & 125 & 42 & 404 & 36 & 23 & 31 & 10 \\
\hline 10 & 168 & 72 & 93 & 22 & 355 & 47 & 20 & 26 & 6 \\
\hline 11 & 114 & 16 & 29 & 16 & 176 & 65 & 9 & 16 & 9 \\
\hline 12 & 187 & 28 & 141 & 35 & 390 & 48 & 7 & 36 & 9 \\
\hline 13 & 237 & 40 & 172 & 14 & 464 & 51 & 9 & 37 & 3 \\
\hline 14 & 203 & 44 & 132 & 8 & 386 & 52 & 11 & 34 & 2 \\
\hline 15 & 137 & 225 & 7 & 0 & 370 & 37 & 61 & 2 & 0 \\
\hline 16 & 177 & 261 & 122 & 0 & 559 & 32 & 47 & 22 & 0 \\
\hline Whole river & 2174 & 1776 & 1178 & 768 & 5896 & 37 & 30 & 20 & 13 \\
\hline
\end{tabular}

Table 4. LULC of the Brahmaputra river in 2014.

\begin{tabular}{|c|c|c|c|c|c|c|c|c|c|}
\hline \multirow[b]{3}{*}{ Reach no. } & \multicolumn{5}{|c|}{ Area $\left(\mathrm{km}^{2}\right)$} & & & & \\
\hline & \multirow[b]{2}{*}{ Water } & \multicolumn{3}{|c|}{ Sandbar/Island } & \multirow[b]{2}{*}{ Total } & \multicolumn{4}{|c|}{ Area covered $(\%)$} \\
\hline & & Sand & Agriculture & Vegetation & & Water & Sand & Agriculture & Vegetation \\
\hline 1 & 100 & 177 & 52 & 90 & 420 & 24 & 42 & 12 & 21 \\
\hline 2 & 136 & 221 & 58 & 69 & 484 & 28 & 46 & 12 & 14 \\
\hline 3 & 94 & 189 & 0 & 100 & 383 & 24 & 49 & 0 & 26 \\
\hline 4 & 76 & 149 & 3 & 77 & 305 & 25 & 49 & 1 & 25 \\
\hline 5 & 110 & 162 & 54 & 72 & 397 & 28 & 41 & 14 & 18 \\
\hline 6 & 91 & 160 & 101 & 89 & 442 & 21 & 36 & 23 & 20 \\
\hline 7 & 81 & 109 & 12 & 63 & 265 & 30 & 41 & 4 & 24 \\
\hline 8 & 83 & 110 & 0 & 51 & 244 & 34 & 45 & 0 & 21 \\
\hline 9 & 104 & 150 & 77 & 71 & 402 & 26 & 37 & 19 & 18 \\
\hline 10 & 131 & 189 & 94 & 15 & 429 & 30 & 44 & 22 & 4 \\
\hline 11 & 74 & 83 & 41 & 9 & 207 & 36 & 40 & 20 & 4 \\
\hline 12 & 103 & 83 & 171 & 32 & 389 & 27 & 21 & 44 & 8 \\
\hline 13 & 147 & 168 & 165 & 17 & 498 & 30 & 34 & 33 & 3 \\
\hline 14 & 143 & 129 & 126 & 11 & 409 & 35 & 31 & 31 & 3 \\
\hline 15 & 140 & 150 & 106 & 4 & 401 & 35 & 37 & 27 & 1 \\
\hline 16 & 170 & 176 & 234 & 5 & 585 & 29 & 30 & 40 & 1 \\
\hline Whole river & 1783 & 2404 & 1295 & 776 & 6258 & 29 & 38 & 21 & 12 \\
\hline
\end{tabular}

took place during 1973-1994 compared to 19942014. Average shift of the main channel was $3 \mathrm{~km}$ during 1973-1994 and $2 \mathrm{~km}$ during 1994-2014. Total erosion during 1973-1994 was $1166 \mathrm{~km}^{2}$ with $564 \mathrm{~km}^{2}$ in the north bank and $602 \mathrm{~km}^{2}$ in the south bank. Again, total deposition during 1973-1994 was $172 \mathrm{~km}^{2}$ with $96 \mathrm{~km}^{2}$ in the north bank and 76 $\mathrm{km}^{2}$ in the south bank. Compared to 1973-1994, there was less erosion $\left(589 \mathrm{~km}^{2}\right)$ and more deposition (197 km²) during 1994-2014. Total erosion during 1973-2014 (1557 km²) was not numerically equal to the erosional area of 1973-1994 (1166 km²) 
and 1994-2014 (589 $\left.\mathrm{km}^{2}\right)$ as some area eroded during 1973-1994 was deposited in 1994-2014. Similarly, some area deposited during 1973-1994 was affected by erosion in a later period (e.g., reach no. $2,6,7,8,11,13$ and 14$)$.

\subsection{LULC in the Brahmaputra during the post-monsoon months}

Increased braiding and erosion-deposition has resulted in different LULC of an alluvial river including the floodplains. The dynamic nature of the Brahmaputra and its tributaries modifies the floodplains frequently, at times to an undesired magnitude (Goswami et al. 1999; Kotoky et al. 2004; Sarma and Phukan 2004; Das et al. 2012; Lahiri and Sinha 2012). Associated changes in the LULC (linking it with river dynamics) are rarely documented in quantitative terms (Kotoky et al. 2012; Mondal et al. 2013) which are essential preconditions for the formulation of the floodplain
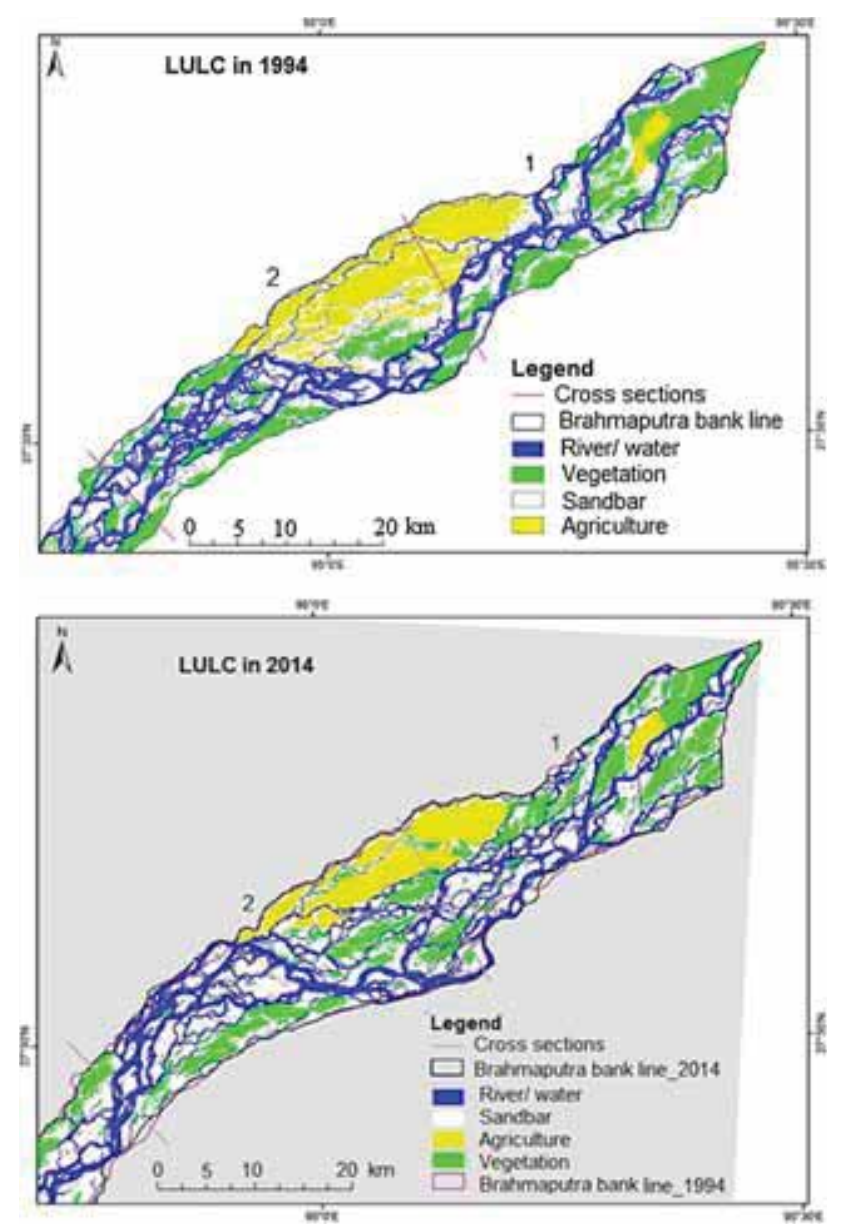

Figure 4. LULC of the river bed of the Brahmaputra in reach no. 1 and 2 during the post-monsoon months of 1994 and 2014. management programme. While both river bank erosion and scouring of the river bed lead to the formation of new sandbars and braids due to the new deposition of the eroded sediments, thereby influencing channel migration, the ever dynamic nature of the flow subsequently results in the erosion of the other parts of bank and bars in an attempt to reach a new equilibrium in channel geometry and morphology.

LULC is linked to the erosion and deposition of the river since the land cover is under constant change in a dynamic landscape constantly shaped newly by the ongoing erosion and deposition each season. Often it is the vegetated and the sparsely vegetated banks and sandbars that get eroded and, consequently, barren sandbars emerge. Although the land cover undergoes a significant change leading to the need for a reevaluation of LULC, precise quantification and location of the corresponding erosion-deposition is challenging.
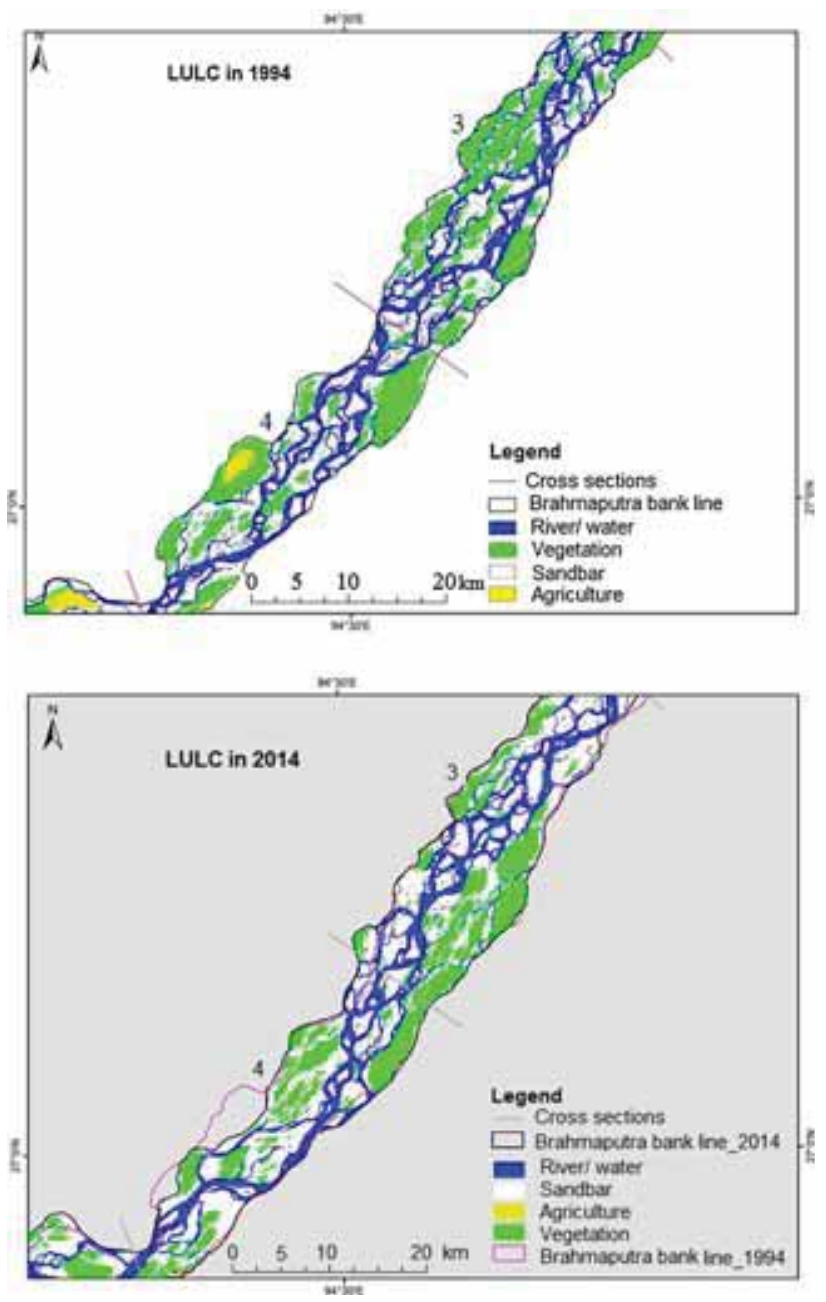

Figure 5. LULC of the river bed of the Brahmaputra in reach no. 3 and 4 during the post-monsoon months of 1994 and 2014. 

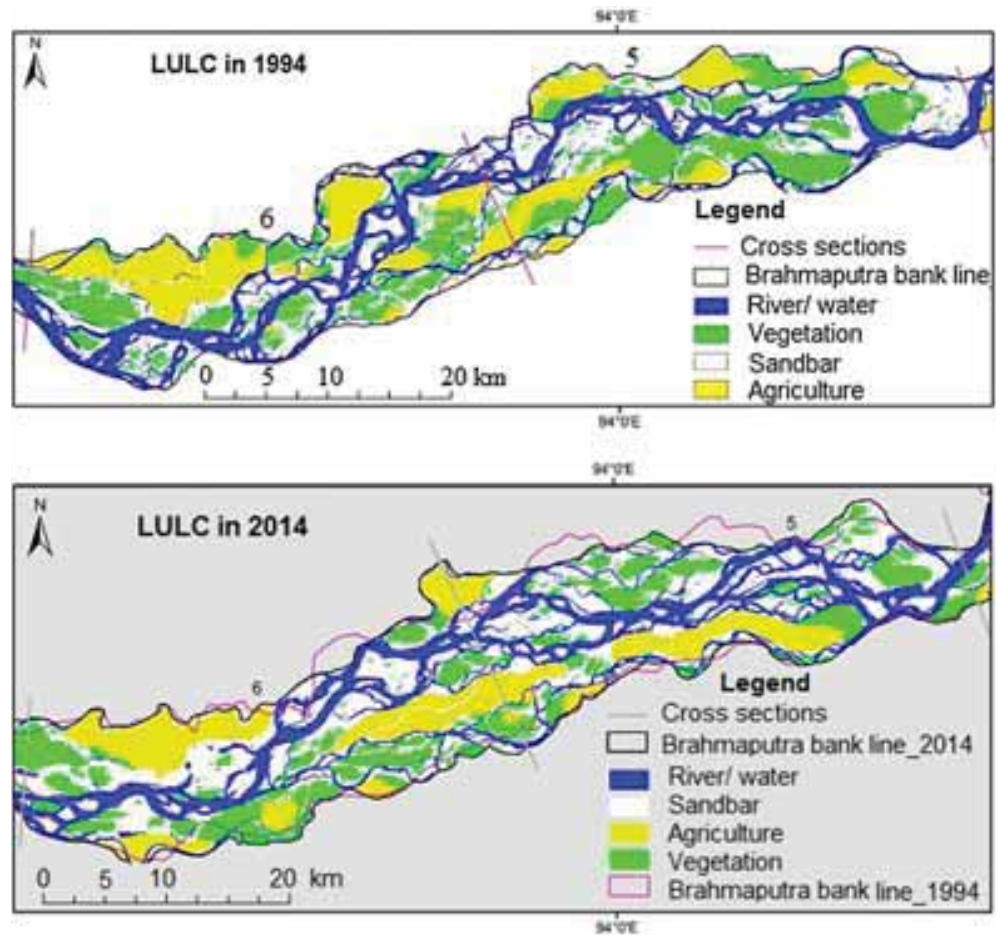

Figure 6. LULC of the river bed of the Brahmaputra in reach no. 5 and 6 during the post-monsoon months of 1994 and 2014.
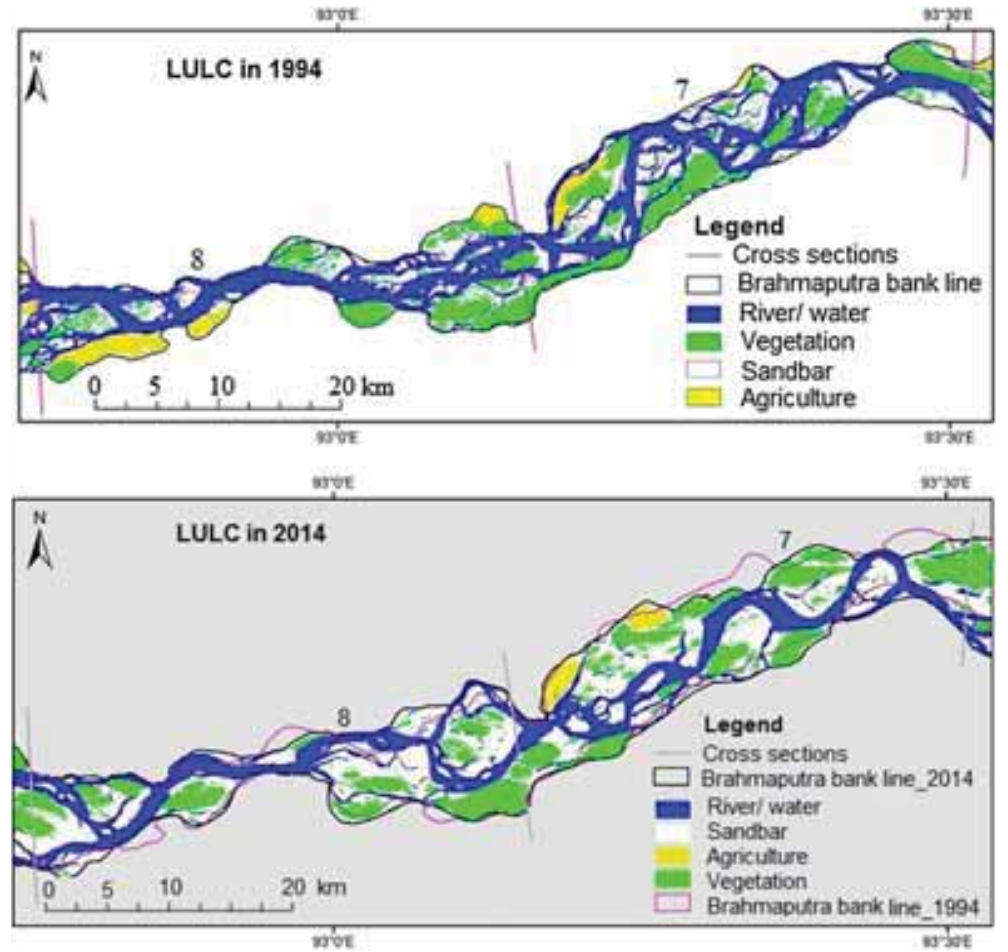

Figure 7. LULC of the river bed of the Brahmaputra in reach no. 7 and 8 during the post-monsoon months of 1994 and 2014 .

LULC of the Brahmaputra river in 1994 and 2014 is shown in tables 3 and 4 and figures $4-11$. In $1994,37 \%$ area of the river bed was occupied by water, i.e., river and $63 \%$ area was bars, out of which $30 \%$ was sand and $33 \%$ was under agricultural practice and vegetation. Thus, more than 

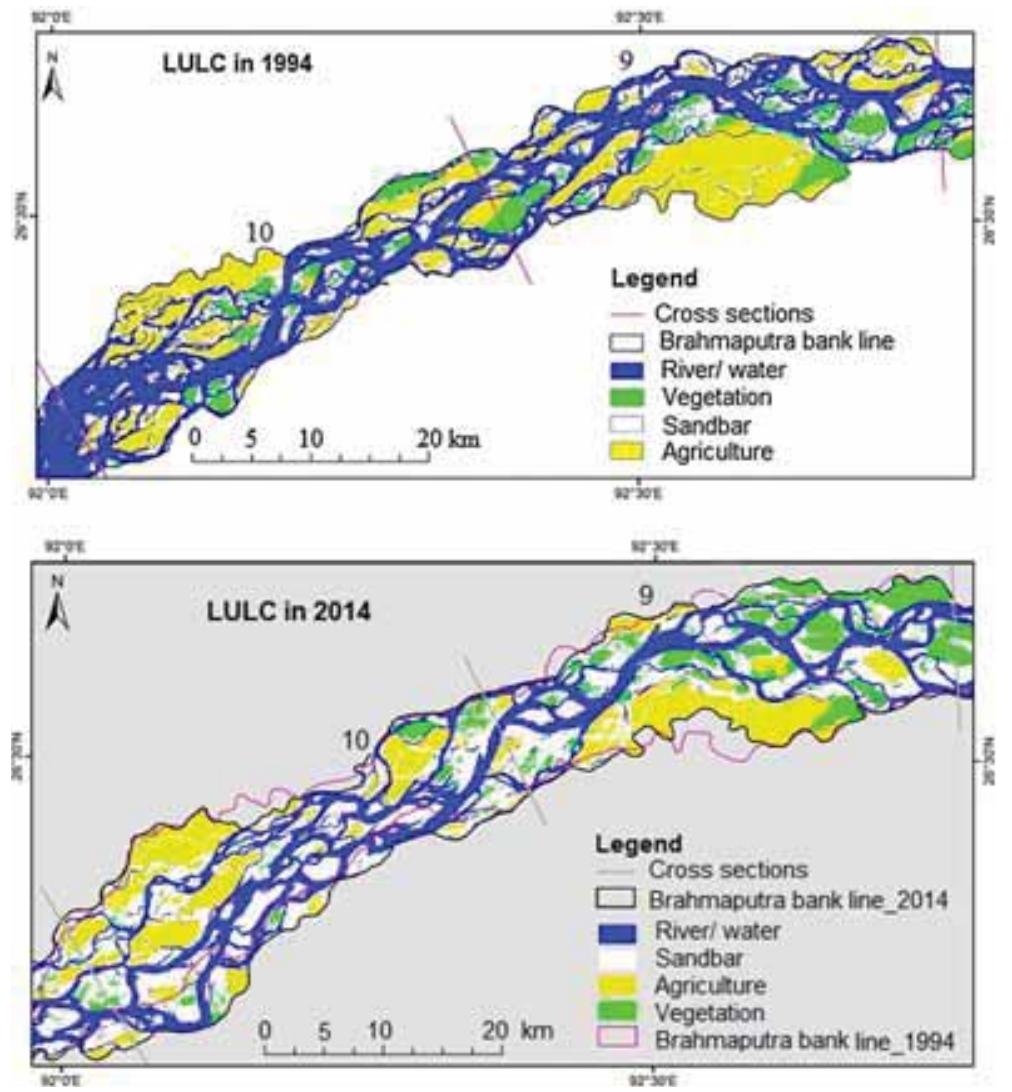

Figure 8. LULC of the Brahmaputra in reach no. 9 and 10 in 1994 and 2014.
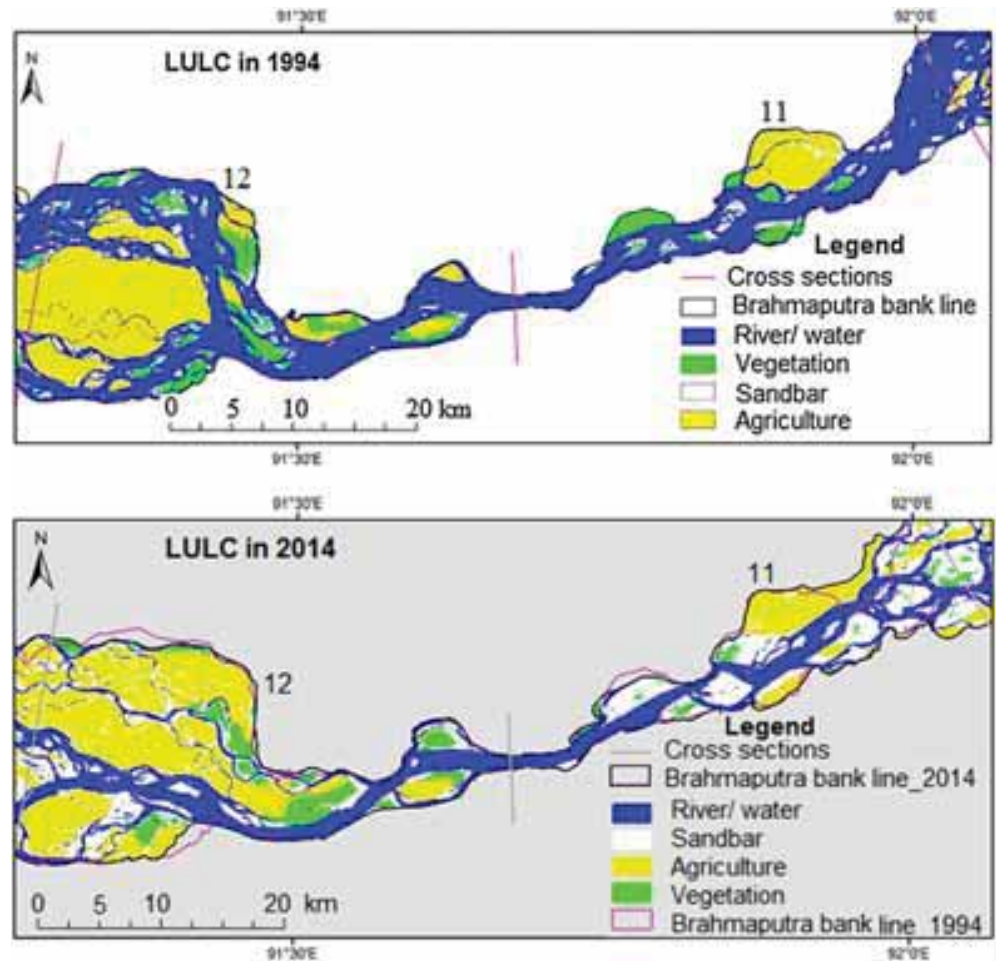

Figure 9. LULC of the river bed of the Brahmaputra in reach no. 11 and 12 during the post-monsoon months of 1994 and 2014. 

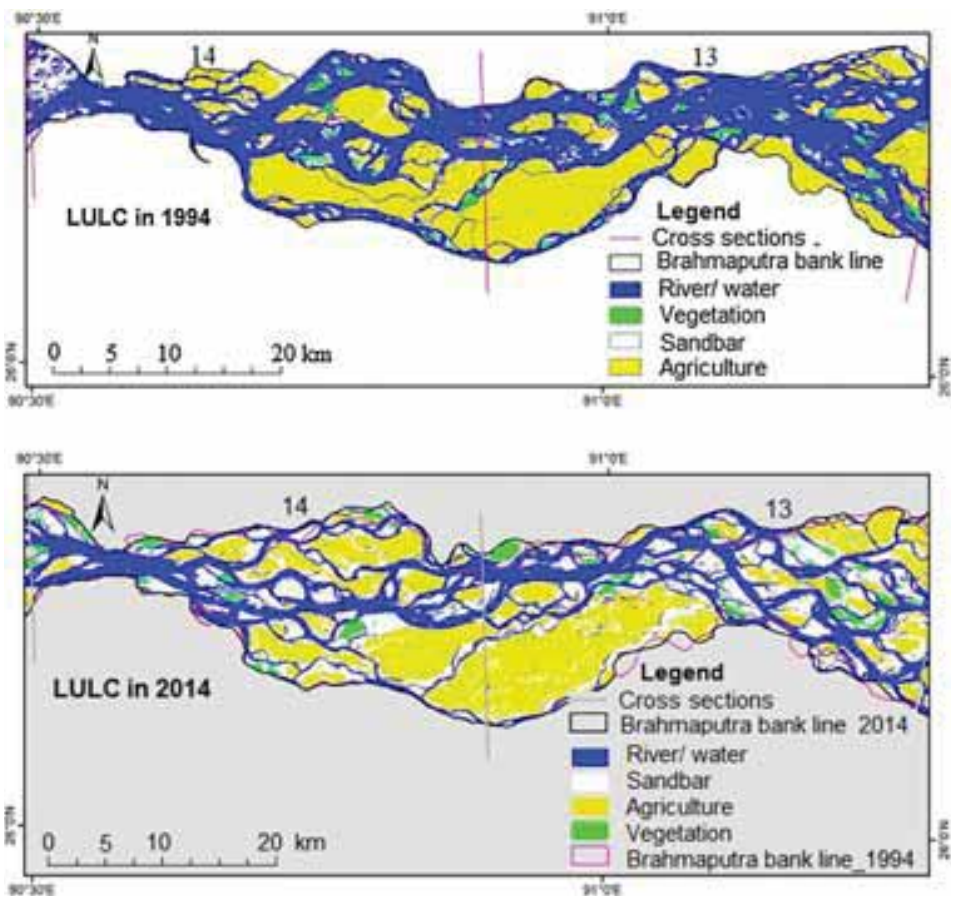

Figure 10. LULC of the river bed of the Brahmaputra in reach no. 13 and 14 during the post-monsoon months of 1994 and 2014.

$60 \%$ of the river bed of the Brahmaputra was covered by temporary sandbars and permanent islands in the post-monsoon months. However, reaches had a varied amount (range $34-79 \%$ ) of sandbars and islands.

In $2014,29 \%$ of the area was occupied by channels and $71 \%$ of the area was occupied by sandbars, vegetated bars and agriculture. Thus, amount of water in the post-monsoon months has decreased (from $37 \%$ to 29\%) during 1994-2014. All the reaches except reach no. 1, 2 and 5 experienced reduction of water in 2014 compared to 1994. Again, different reaches had an almost uniform (range: $65-76 \%)$ area covered by bars with sand, vegetation and agriculture. Vegetation has decreased and agricultural practices have increased in the different bars and islands of the Brahmaputra during 1994-2014. Agricultural activity has increased in the lower reaches of the Brahmaputra, i.e., reach no. $15(25 \%)$ and $16(18 \%)$. Socio-political factors are a major driving force of LULC change in the upper reaches of the Yangtze river during 1980-2000 (Wu et al. 2008) and the same factor is responsible for the LULC change in the Brahmaputra river, particularly in the lower reaches. The loss of agricultural land and homestead land due to river bank erosion and the growing population in the lower reaches has compelled these riverine people to explore agricultural activities on the river bed during the post-monsoon months.
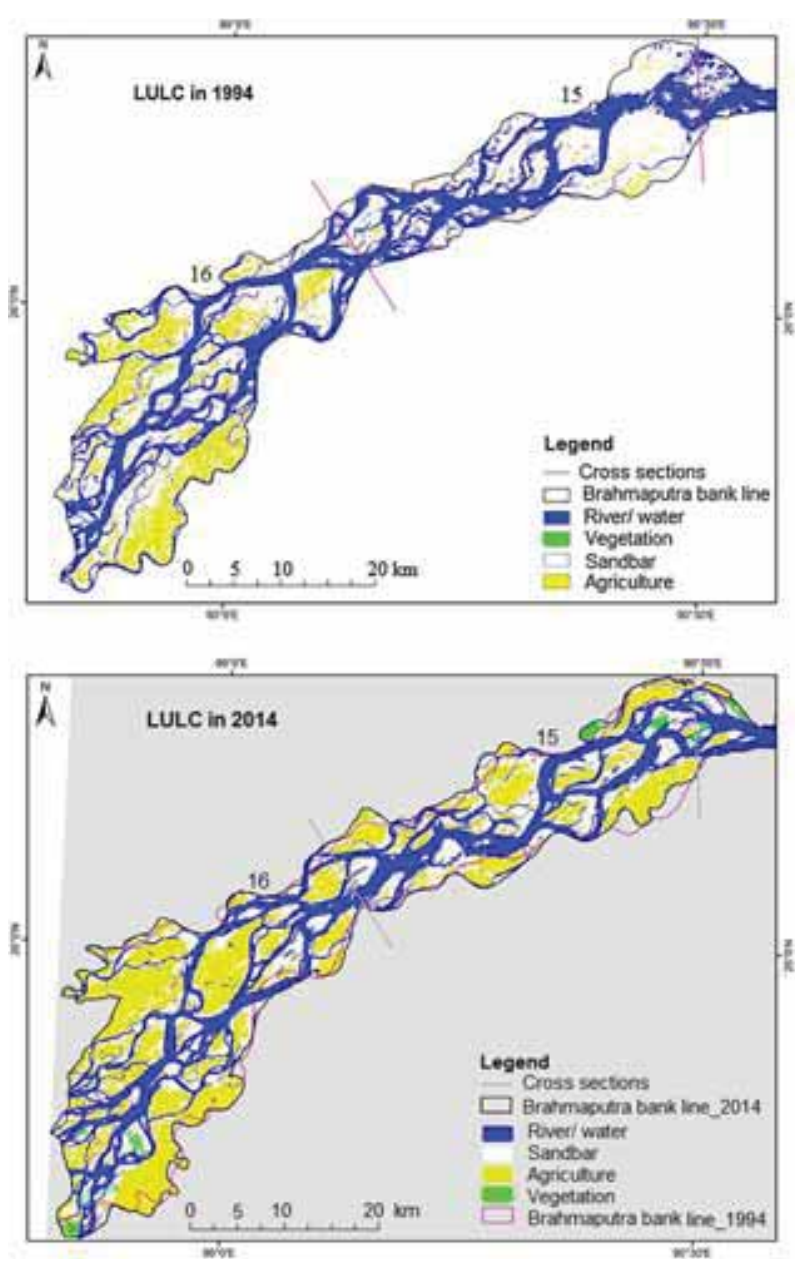

Figure 11. LULC of the river bed of the Brahmaputra in reach no. 15 and 16 during the post-monsoon months of 1994 and 2014. 


\section{Conclusions}

Total area of erosion and deposition in the Brahmaputra river in Assam during 1973-2014 were 1557 and $204 \mathrm{~km}^{2}$, respectively. There was more erosion in the south bank $\left(829 \mathrm{~km}^{2}\right)$ and more deposition in the north bank $\left(122 \mathrm{~km}^{2}\right)$. However, the increased area of the Brahmaputra is not necessarily linked to river bank erosion in every case. The increase in area (28\%) of the Brahmaputra during 1973-2014, besides the bank erosion is also due to the bifurcation of streams without any significant loss of land. LULC change of the Brahmaputra in the post-monsoon months has revealed that the amount of the submerged part in the post-monsoon months has decreased (from $37 \%$ to $29 \%$ ) during 1994-2014. A reduction in natural grassland and forest has been observed with the corresponding increase in agricultural practices in different bars and islands of the Brahmaputra in Assam during 1994-2014. Agricultural activity has increased in the lower reaches of the Brahmaputra, i.e., reach no. 15 (25\%) and 16 (18\%). Sociopolitical factors are responsible for LULC change in the Brahmaputra floodplain particularly in lower reaches. Loss of agricultural land and homestead land from river bank erosion and growing population in the lower reaches has compelled the riverine people to explore agricultural activities in inter fluvial landmasses in post-monsoon months. Identification of sandbars/islands is necessary for better agricultural utilization or other activities in post-monsoon months. Improved regulation and management strategies are also necessary to enhance the retention of land resources in changed socio-political scenario.

\section{Acknowledgements}

This manuscript is a part of the $\mathrm{PhD}$ thesis of the first and corresponding author from the Department of Civil Engineering at Indian Institute of Technology Guwahati, India. The author acknowledges the Department's laboratory and the Institute's library for the facilities available during his PhD work.

\section{References}

ADB 2007 Technical assistance consultant's report, India: Northeastern Integrated Flood and Riverbank Erosion
Management Project (Assam), TA (Phase 1) Workshop Materials; Asian Development Bank.

Charlton R 2008 Fundamentals of fluvial geomorphology; Routledge, London, 97p.

Church M 2006 Bed material transport and the morphology of alluvial river channels; Ann. Rev. Earth Planet. Sci. 34 $325-354$.

Coleman J M 1969 Brahmaputra river: Channel processes and sedimentation; Sedim. Geol. 3 129-239.

Das A K, Sah R K and Hazarika N 2012 Bankline change and the facets of riverine hazards in the floodplain of SubansiriRanganadi, Brahmaputra Valley, India; Nat. Hazards 64 $1015-1028$.

Goswami U, Sarma J N and Patgiri A D 1999 River channel changes of the Subansiri in Assam, India; Geomorphology $30227-244$.

Hay W W 1998 Detrital sediment fluxes from continents to oceans; Chem. Geol. 145 287-323.

Kakati H and Changkakati P P 2013 Proceedings of the Assam water conference 2013; Water Resources Department, Govt. of Assam, Guwahati, 41p.

Knighton D A 1998 Fluvial forms and processes: A new perspective; Arnold, Hodder Headline, PLC, London, UK, 383p.

Kotoky P, Bezbaruah D, Baruah J and Sarma J N 2004 Nature of bank erosion along the Brahmaputra river channel, Assam, India; Curr. Sci. 88 634-640.

Kotoky P, Dutta M K and Borah G C 2012 Changes in land use and land cover along the Dhansiri River Channel, Assam: A remote sensing and GIS approach; J. Geol. Soc. India 79 61-68.

Lahiri S K and Sinha R 2012 Tectonic controls on the morphodynamics of the Brahmaputra River system in the upper Assam valley, India; Geomorphology 169 74-85.

Lane E W 1957 A study of the shape of channels formed by natural streams flowing in erodible material (Missouri River Division Sediment Series No. 9), U.S. Army Engineering Division Missouri River, Corps of Engineers, Nebraska.

Leopold L B and Wolman M G 1957 River channel patterns: Braided, meandering, and straight; U.S. Geol. Surv. Paper 282-B 39-85.

Mahanta C and Saikia L 2015 The Brahmaputra and other rivers of the north-east; In: Living rivers, dying rivers (ed.) Iyer R, Oxford University Press, New Delhi, 155p.

Milliman J D and Meade R H 1983 World-wide delivery of river sediment to the oceans; J. Geol. 91 1-21.

Milliman J D and Syvitski P M 1992 Geomorphic/tectonic control of sediment discharge to the ocean: The importance of small mountainous rivers; J. Geol. 100 525-544.

Mondal M S, Shrama N, Kappas M and Garg P K 2013 Modeling of spatio-temporal dynamics of land use and land cover in a part of Brahmaputra river basin using geoinformatic techniques; Geocarto Int. 28 632-656.

Sarkar A, Garg R D and Sharma N 2012 RS-GIS based assessment of river dynamics of Brahmaputra River in India; J. Water Res. Prot. 4 63-72.

Sarma J N and Phukan M K 2004 Origin and some geomorphological changes of Majuli Island of the Brahmaputra river in Assam, India; Geomorphology 60 1-9.

Schumm S A 1977 The fluvial system; John Wiley \& Sons, New York, 388p.

Schumm S and Kahn H 1972 Experimental study of channel patterns; Geol. Soc. Am. Bull. 83(6) 1755-1770. 
Wu X, Shen Z, Liu R and Ding X 2008 Land use/cover dynamics in response to changes in environmental and socio-political forces in the upper reaches of the Yangtze River, China; Sensors 8 8104-8122.
Yao Z, Ta W, Jia X and Xiao J 2011 Bank erosion and accretion along the Ningxia-Inner Mongolia reaches of the Yellow River from 1958 to 2008; Geomorphology $\mathbf{1 2 7}$ 99-106.

Corresponding editor: N V Chalapathi RaO 